\title{
LDPE/Bismuth Oxide Nanocomposite: Preparation, Characterization and Application in X-ray Shielding
}

\author{
Saad Alshahri, Mohammed Alsuhybani *, Eid Alosime (D, Mansour Almurayshid *, Alhanouf Alrwais \\ and Salha Alotaibi
}

check for updates

Citation: Alshahri, S.; Alsuhybani, M.; Alosime, E.; Almurayshid, M.;

Alrwais, A.; Alotaibi, S.

LDPE/Bismuth Oxide

Nanocomposite: Preparation,

Characterization and Application in X-ray Shielding. Polymers 2021, 13, 3081. https://doi.org/10.3390/ polym13183081

Academic Editors: Chih-Chia Cheng, Jia-Wun Li and Chih-Wei Chiu

Received: 24 August 2021

Accepted: 10 September 2021

Published: 13 September 2021

Publisher's Note: MDPI stays neutral with regard to jurisdictional claims in published maps and institutional affiliations.

Copyright: (c) 2021 by the authors. Licensee MDPI, Basel, Switzerland. This article is an open access article distributed under the terms and conditions of the Creative Commons Attribution (CC BY) license (https:// creativecommons.org/licenses/by/ $4.0 /)$.
Nuclear Science Research Institute, King Abdulaziz City for Science and Technology, Riyadh 11442, Saudi Arabia; sshahri@kacst.edu.sa (S.A.); alosimi@kacst.edu.sa (E.A.); aalrwais@kacst.edu.sa (A.A.); sealotaibi@kacst.edu.sa (S.A.)

* Correspondence: sohybani@kacst.edu.sa (M.A.); malmurayshid@kacst.edu.sa (M.A.)

\begin{abstract}
Recently developed polymer-based composites could prove useful in many applications such as in radiation shielding. In this work, the potential of a bismuth oxide $\left(\mathrm{Bi}_{2} \mathrm{O}_{3}\right)$ nanofiller based on an LDPE polymer was developed as lead-free X-ray radiation shielding offering the benefits of lightness, low-cost and non-toxic compared to pure lead. Three different LDPE-based composites were prepared with varying weight percentages of $\mathrm{Bi}_{2} \mathrm{O}_{3}: 5 \%, 10 \%$ and $15 \%$. The characterizations were extended to include structural properties, physical features, mechanical and thermal properties, and radiation shielding efficiency for the prepared nanocomposites. The results revealed that the incorporation of the $\mathrm{Bi}_{2} \mathrm{O}_{3}$ nanofiller into an LDPE improved the density of the composites. There was also a slight increase in the tensile strength and tensile modulus. In addition, there was a clear improvement in the efficiency of the shield when fillers were added to the LDPE polymer. The $\mathrm{LDPE}+\mathrm{Bi}_{2} \mathrm{O}_{3}(15 \%)$ composite needed the lowest thickness to attenuate $50 \%$ of the incident $\mathrm{X}$-rays. The $\mathrm{LDPE}+\mathrm{Bi}_{2} \mathrm{O}_{3}(15 \%)$ polymer can also block around $80 \%$ of X-rays at $47.9 \mathrm{keV}$. In real practice, a thicker shield of the proposed composite materials, or a higher percentage of the filler could be employed to safely ensure the radiation is blocked.
\end{abstract}

Keywords: polymeric nanocomposite; $\mathrm{LDPE} ; \mathrm{Bi}_{2} \mathrm{O}_{3}$; radiation shielding; attenuation of $\mathrm{X}$-ray radiation

\section{Introduction}

The overall unique properties of various composite materials have recently attracted a wide range of scientific research regarding radiation protection due to the materials' low weight, low manufacturing cost, mechanical strength, flexibility, and chemical stability [1] Lead $(\mathrm{Pb})$ has traditionally been employed as a shield since it has a high density and high efficiency in form of sheets, plates, foils, laminates, bricks, and blocks [2,3]. Nevertheless, the use of $\mathrm{Pb}$ is limited and it is unsuitable for some specific applications that require low cost, flexibility, chemical stability, mechanical strength, and lightness [4]. Polymer composites are an attractive option for radiation shielding because of their many advantages including being environmentally friendly, light, non-toxic, and flexible [5]. Consequently, diverse researchers have used various types of polymers as a matrix and have included fillers that provide reinforcement, depending on their overall application. The most used composites in X-and $\gamma$-rays shields are polymeric materials reinforced by metal and metal oxide [6-9]. As noted in the literature, metal-polymer composites generally combine two dissimilar components forming a light lattice together with $\mathrm{Z}$ particles [10]. The increased shielding properties of the metal-polymer are because of the uniform distribution of metal and metal oxide particles within the defined matrix [11].

Investigators have focused and reported several polymer matrices that can be used as $\mathrm{X}$ - and $\gamma$-ray shields. These polymer matrices include bismuth oxide $\left(\mathrm{Bi}_{2} \mathrm{O}_{3}\right)$ filled poly (methyl methacrylate) composites, a high-density polyethylene (HDPE) composite that is loaded with tungsten $(\mathrm{W})$, molybdenum sulfide $\left(\mathrm{MoS}_{2}\right)$, boron carbide $\left(\mathrm{B}_{4} \mathrm{C}\right)$, micro-and 
nanosized tungsten oxide $\left(\mathrm{WO}_{3}\right)$ dispersed emulsion polyvinyl chloride (EPVC) polymer composites, lead oxide filled isophthalic resin polymer composites, silicone rubber composites that contain bismuth content, polymer bricks, polyester composites that are reinforced with zinc, composites of HDPE with zinc oxide, lead oxide, and cadmium oxide [12-21]. The research attention has increasingly turned toward the overall effects of the presence of nanoparticles within the shielding materials, because of the novel uses of the materials [22]. The quantum effects and increase in the surface-to-volume ratio factor of nanoparticles were reported as the main factors that bring about dissimilar behaviors of the nano and microparticles. The outlined parameters affect the mechanical, thermal and shielding properties of the materials in some cases [23]. Because of induced agglomeration, the dispersion of nanoparticles into the overall polymer matrix is known to be more challenging than the dispersion of micro-sized particles [24]. Accordingly, the prominent features known to nano-scale particles than microparticles are known to cause an impressive increase in the resultant attenuation coefficient. As asserted in various studies, combining two phases of matrix and reinforcement is more complex and diverse than each individual phase [25].

Many researchers have performed studies on $\mathrm{Pb}$-free composite shields. For example, one study designed and fabricated composites that consisted of HDPE mixed with microsized and nano-sized cadmium oxide particles for attenuation of photon beams with energy that ranged from $59.53 \mathrm{keV}$ up to $1408.01 \mathrm{keV}$ [19]. It was established that the nanoscale reinforced HDPE enhanced the overall shielding properties, particularly at lower photon energies. Another study was conducted on a new polyvinyl alcohol (PVA) $/ \mathrm{WO}_{3}$ composite based on the Monte Carlo N-Particle (MCNP) simulation code [26]. It was noted that the PVA $/ \mathrm{WO}_{3}$ composite could be considered as a shield for photon energy at the levels of $662,778,964,1112,1170,1130$, and $1407 \mathrm{keV}$. In addition, Atashi et al. conducted some fabrication of flexible silicone rubber $/ \mathrm{W} / \mathrm{Bi}_{2} \mathrm{O}_{3}$ using the technique of open mold cast [5]. The final composites possessed higher attenuation coefficients. Furthermore, it was established that increasing $\mathrm{Bi}_{2} \mathrm{O}_{3}$ in composites decreases the agglomeration of fillers. However, the composite of PVA containing $0-40 \mathrm{wt} \%$ filler loading $\left(\mathrm{Bi}_{2} \mathrm{O}_{3}\right.$ and $\left.\mathrm{WO}_{3}\right)$ used in X-ray shielding is reported to play an important role in determining the density and the thickness of the composite sample [9].

Varying the quantity of tungsten nanopowder yielded improvement in thermophysical, radiation shielding and mechanical properties by [27]. In addition, concentration ranges of $30-70 \mathrm{wt} \% \mathrm{Bi}_{2} \mathrm{O}_{3}$ were dispersed in carboxylated nitrile butadiene rubber latex films [28]. The films effectively attenuated low-energy photon beams. The overall effect of density on the composites' suitability as radiation shield was studied using X-rays [29]. The attenuation performance against radiation was studied by varying the amounts of powdered fillers lead oxide and $\mathrm{WO}_{3}$ added to low-density polyethylene (LDPE). The results of the study indicated that samples with higher filler loads showed good attenuation performance against radiation [30].

In the current study, LDPE resin was chosen as a matrix duet to its superior mechanical and chemical properties. $\mathrm{Bi}_{2} \mathrm{O}_{3}$ was chosen for an alternative $\mathrm{X}$-ray protective filler since it has key potential properties such as high density, high melting point, low conductivity, and is available in fine powder form. Therefore, the primary experiments aimed at furthering the understanding of LDPE nanocomposites. LDPE $+\mathrm{Bi}_{2} \mathrm{O}_{3}$ composites with different loadings of nano $\mathrm{Bi}_{2} \mathrm{O}_{3}$ were prepared via melt compounding. The study then conducted a study of X-ray attenuation, structure, mechanical, and thermal characteristics of $\mathrm{Bi}_{2} \mathrm{O}_{3}$ filled polymer composites. The results from this work would not only offer exciting possibilities for new, effective and safe X-ray protective LDPE nanocomposites but also highlight the potential of these new composite materials to be further developed for radiation shielding applications. 


\section{Materials and Methods}

\subsection{Materials}

A commercial sample of LDPE (density: $0.93 \mathrm{~g} \mathrm{~cm}^{-3}$ ) was obtained from the Saudi Arabian Basic Industries Corporation (SABIC),(Riyadh, Saudi Arabia), under the trade name LDPE HP 0722N. Bismuth oxide nano powder was obtained from (Alfa Aesar, Kandel, Germany) with particle size smaller than $100 \mathrm{~nm}$.

\subsection{Nanocomposite Preparation}

The Xplore conical twin-screw extruder was used to prepare the following samples: Pure LDPE, $5 \mathrm{wt} \%, 10 \mathrm{wt} \%$ and $15 \mathrm{wt} \%$ of $\mathrm{Bi}_{2} \mathrm{O}_{3}$ for LDPE $+\mathrm{Bi}_{2} \mathrm{O}_{3}$ nanocomposites. Firstly, an electrical balance (Sartorius Analytical, Karlsruhe, Germany) weighted LDPE and $\mathrm{Bi}_{2} \mathrm{O}_{3}$ with an accuracy $\pm 0.0001 \mathrm{~g}$. Subsequently, $20 \mathrm{~g}$ of LDPE with a specified weight percentage of $\mathrm{Bi}_{2} \mathrm{O}_{3}$ was fed into a mini twin-screw extruder at $170{ }^{\circ} \mathrm{C}$, for $10 \mathrm{~min}$. The rotator speed was set to 100 rounds per minute (rpm) to ensure a uniformly mixed composite.

The fully mixed sample was then put into a stainless-steel frame $\left(100 \times 100 \times 1 \mathrm{~mm}^{3}\right)$ to be hot presses between two layers. The pressing was carried out by using a hydraulic press preheated at $170{ }^{\circ} \mathrm{C}$ for $3 \mathrm{~min}$. The pressure was then gradually raised to $100 \mathrm{kN}$ for another $10 \mathrm{~min}$. The sample was left in the press for $20 \mathrm{~min}$ to cool down to room temperature. Finally, the resulting sheet was taken out of the mold and cut into circular samples of $25 \mathrm{~mm}$ in diameter to perform radiation-shielding tests and into dumbbell shape for tensile testing according to ASTM D638.

\section{Characterization}

\subsection{X-ray Differentiation}

X-ray diffraction (XRD) analysis was carried out using JOEL instruments (Tokyo, Japan) using $\mathrm{Cu} \mathrm{K} \alpha$ radiation $(\lambda=0.1540 \mathrm{~nm}$, a tube operated at $40 \mathrm{kV}$ and a filament current of $40 \mathrm{~mA}$, the Bragg's angle (20) was in the range of $5^{\circ}-80^{\circ}$ using 0.01 step with and $1 \mathrm{~s}$ time count). All data were recorded and analyzed using the machine software. The crystal size was calculated by the Scherer equation:

$$
\mathrm{D}=\frac{\mathrm{K} \lambda}{\beta \cos \theta}
$$

where $D$ is the crystallite size $(\mathrm{nm}), \mathrm{K}$ is the crystallite shape factor $(\mathrm{K}=0.9), \lambda$ is the $\mathrm{X}$-ray wavelength of $\mathrm{Cu}$ (equal $=0.154 \mathrm{~nm}$ ) and $\beta$ is the full width half maximum (FWHM) of XRD diffraction peak in radians.

\subsection{Scanning Electron Microscope (SEM)}

The surface morphology and dispersion of the nanocomposite were studied by SEM using JEOL (Tokyo, Japan). The samples were prepared as follows: the specimen was stuck on a $10 \mathrm{~mm}$ diameter carbon tab attached to the top of the aluminum pin tube. Then, the sample was coated with gold using a sputter coater. The coating exposure was $2 \mathrm{~min}$.

\subsection{Density Measurements}

The experimental and calculated densities were evaluated using the Archimedes method (water as an immersing medium) for the mixture. The relative density of pure $\mathrm{Bi}_{2} \mathrm{O}_{3}$ and LDPE were calculated to 8.9 and $0.93 \mathrm{~g} . \mathrm{cm}^{-3}$ respectively using the Mettler Toledo XS204 instrument (Greifensee, Switzerland).

\subsection{Tensile Testing}

Tensile testing was conducted by a tensile machine (Instron 5982, Grove city, PA, USA) according to ASTM D638, (dumbbell samples cut from pressed sheets $1 \mathrm{~mm}$ thickness) at crosshead speed $50 \mathrm{~mm} \mathrm{~min}^{-1}$. The results are the average of at least five measurements. The tensile strength, Young's modulus and elongation at the break of the composite were calculated. 


\subsection{Thermal Analysis by TGA}

The thermal behavior of the sample was evaluated using a thermogravimetric analyzer (TGA 1, Perkin Elmer, Shelton, CT, USA). Each sample was heated from room temperature to $700{ }^{\circ} \mathrm{C}$ at a rate of $10{ }^{\circ} \mathrm{C} \mathrm{min}^{-1}$.

\section{Results and Discussion}

\subsection{Density Measurements}

In the present study, density was used to represent the physical property of LDPE composites. A high-density metal oxide nanofiller was used to improve some properties of the respective thermoplastic composition and density. Table 1 illustrates the test results via the resultant density of LDPE composites taken as a function of $\mathrm{Bi}_{2} \mathrm{O}_{3}$ content. Considering the rule of mixture, the overall density of any given particulate-filled composite is known to be related to the density of its constituent particles. As noted in Table 1, the overall density of the composite increased as the amount loading of $\mathrm{Bi}_{2} \mathrm{O}_{3}$ increased. The increase can be linked to the density range of $\mathrm{Bi}_{2} \mathrm{O}_{3}$ which is $8.9 \mathrm{~g} \mathrm{~cm}^{-3}$ : much higher than LDPE's density of $0.93 \mathrm{~g} \mathrm{~cm}^{-3}$. The density range of LDPE composites was between $0.961-1.060 \mathrm{~g} \mathrm{~cm}^{-3}$. Ambika et al. in which the density of unsaturated polyester (UP) was found to increase the overall increase in the $\mathrm{Bi}_{2} \mathrm{O}_{3}$ filler content reported a similar phenomenon [31]. This was related to the fact that $\mathrm{Bi}_{2} \mathrm{O}_{3}$ has a higher density compared to UP. As explained by Pavlenko et al., increasing the $\mathrm{Bi}_{2} \mathrm{O}_{3}$ nanoparticle filler content within the polyimide (PI) composites results in an increase in the density of $\mathrm{PI}$, since $\mathrm{Bi}_{2} \mathrm{O}_{3}$ is known to have a higher density compared to other formulation contents [32]. In the experiment, the highest reported density was $1.07 \mathrm{~g} \mathrm{~cm}^{-3}$ for an LDPE with $15 \mathrm{wt} \%$ of $\mathrm{Bi}_{2} \mathrm{O}_{3}$, yielding an overall increment of approximately $13 \%$ in density in comparison to pure LDPE. On the other hand, composites of an LDPE with $5 \mathrm{wt} \% \mathrm{Bi}_{2} \mathrm{O}_{3}$ content showed the lowest density, at about $0.961 \mathrm{~g} \mathrm{~cm}^{-3}$.

Table 1. The density results of LDPE and its composites.

\begin{tabular}{ccccc}
\hline Sample Code & $\begin{array}{c}\text { Composition } \\
\text { (wt\%) }\end{array}$ & $\begin{array}{c}\text { Density } \\
\left.\mathbf{( g ~ c m}^{-3}\right) \\
\left(\begin{array}{c}\text { Experimental) } \\
\text { ( })\end{array}\right.\end{array}$ & $\begin{array}{c}\text { Density } \\
\left(\mathbf{g ~ c m}^{-3}\right) \\
(\text { Calculated) }\end{array}$ & Error (\%) \\
\hline Pure LDPE & Pure LDPE & 0.926 & 0.930 & 0.430 \\
LB-5 & LDPE $(95 \%)+\mathrm{Bi}_{2} \mathrm{O}_{3}(5 \%)$ & 0.961 & 0.973 & 1.293 \\
LB-10 & LDPE $(90 \%)+\mathrm{Bi}_{2} \mathrm{O}_{3}(10 \%)$ & 1.010 & 1.021 & 3.270 \\
LB-15 & LDPE $(85 \%)+\mathrm{Bi}_{2} \mathrm{O}_{3}(15 \%)$ & 1.060 & 1.074 & 8.762 \\
\hline
\end{tabular}

\subsection{Thermal Stability}

In this study, an overall determination of thermal characteristics was carried out between $25-700{ }^{\circ} \mathrm{C}$. Figure 1 illustrates the TGA curves of pure LPDE and those of the composites containing up to $15 \mathrm{wt} \%$ of $\mathrm{Bi}_{2} \mathrm{O}_{3}$. Figure 1 affirms that pure LDPE is stable up to $459.1^{\circ} \mathrm{C}$ without the general loss of mass on the respective TGA curve. Complete thermal decomposition of the LDPE occurs at $500{ }^{\circ} \mathrm{C}$. The introduction of inorganic filler results in a significant increase in the overall thermal stability of the respective polymers [33-35]. This is exemplified clearly by LDPE $+\mathrm{Bi}_{2} \mathrm{O}_{3}(15 \%)$. In the end, an increase in the $\mathrm{Bi}_{2} \mathrm{O}_{3}$ content results in a decrease in the rate of mass loss for the composites. Nonetheless, a slight mass loss in the composites starts at $80-120^{\circ} \mathrm{C}$. This is related to the loss of sorbed-water and hydroxyl water that is contained in the $\mathrm{Bi}_{2} \mathrm{O}_{3}$ [36]. The data on the thermal stability of various composites are outlined in Table 2. It can be concluded from the data in Table 2 and Figure 1 that the overall thermal stability of the LDPE is generally less than that of $\mathrm{LDPE}+\mathrm{Bi}_{2} \mathrm{O}_{3}$ nanocomposites. This is a clear confirmation of the fact that the thermal stability of various inorganic compounds is greater than those of polymers. Furthermore, the overall increase in thermal stability of such composites could be linked to an increase in the density of $\mathrm{Bi}_{2} \mathrm{O}_{3}$. In the experiment, the char yield of $\mathrm{LDPE}+\mathrm{Bi}_{2} \mathrm{O}_{3}$ nanocomposite was found to be $4.6 \%, 9.6 \%$, and $13.2 \%$ (respectively) higher than that of respective pure 
LDPE that was $0.3 \%$ at $600{ }^{\circ} \mathrm{C}$. The reported values affirm that the dispersion of $\mathrm{Bi}_{2} \mathrm{O}_{3}$ into the polymer was indeed great thus closer to the initial percentage of weight added. Table 3 outlines the burning characteristic of LDPE that contained various loadings of $\mathrm{Bi}_{2} \mathrm{O}_{3}$. The present study assessed whether the overall presence of metal oxide in relation to the composition was consistent with the outlined theoretical quantity of $\mathrm{Bi}_{2} \mathrm{O}_{3}$. Considering the range of experimental error, the estimated amount of metal oxide is in agreement with the loading weight percentage of $\mathrm{Bi}_{2} \mathrm{O}_{3}$ to LDPE.

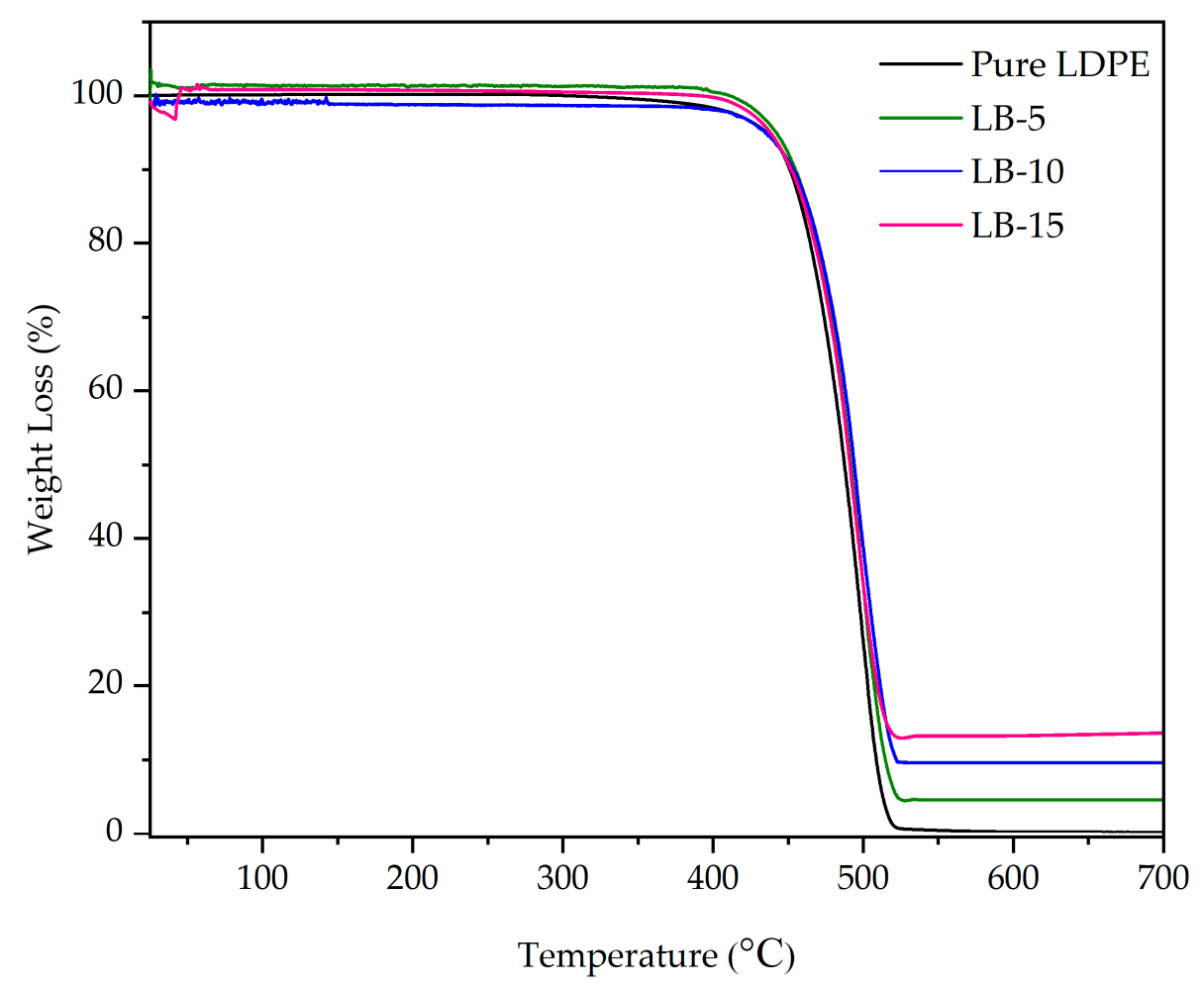

Figure 1. TGA thermograms for pure LDPE and LDPE/ $\mathrm{Bi}_{2} \mathrm{O}_{3}$ composites.

Table 2. Summary of the TGA thermograms for pure LDPE and LDPE $+\mathrm{Bi}_{2} \mathrm{O}_{3}$ composites.

\begin{tabular}{ccccc}
\hline Sample & $\begin{array}{c}\mathbf{B i}_{2} \mathbf{O}_{\mathbf{3}} \text { Loading } \\
(\mathbf{w t} \text { \%) }\end{array}$ & $\begin{array}{c}\text { Onset Temp } \\
\left({ }^{\circ} \mathbf{C}\right)\end{array}$ & $\begin{array}{c}\text { High Peak } \\
\text { Temp }\left({ }^{\circ} \mathbf{C}\right)\end{array}$ & $\begin{array}{c}\text { Weight Loss at } \\
\mathbf{6 0 0}{ }^{\circ} \mathbf{C}(\mathbf{\%})\end{array}$ \\
\hline Pure LDPE & 0 & 459 & 500 & 0.3 \\
LB-5 & 5 & 459 & 500.2 & 4.6 \\
LB-10 & 10 & 461 & 501.2 & 9.6 \\
LB-15 & 15 & 454 & 500.6 & 13.2 \\
\hline
\end{tabular}

Table 3. Burn test of pure LDPE and LDPE $+\mathrm{Bi}_{2} \mathrm{O}_{3}$ composites.

\begin{tabular}{cccc}
\hline \multirow{2}{*}{ Sample } & \multicolumn{2}{c}{$\mathbf{B i}_{\mathbf{2}} \mathbf{O}_{\mathbf{3}}$ Loading $\left.\mathbf{( w t} \%\right)$} & \\
\cline { 2 - 3 } & $\begin{array}{c}\text { The Theoretical } \\
\text { Values }\end{array}$ & $\begin{array}{c}\text { The Experimental } \\
\text { Values }\end{array}$ & Error (\%) \\
\hline Pure LDPE & 0 & 0 & 0 \\
LB-5 & 5.00 & 4.49 & 10.2 \\
LB-10 & 10.0 & 9.16 & 8.37 \\
LB-15 & 15.0 & 14.5 & 3.39 \\
\hline
\end{tabular}

\subsection{Mechanical Properties}

Table 4 illustrates mechanical properties such as tensile strength, elongation at break and Young's modulus of LDPE composites taken as a function of $\mathrm{Bi}_{2} \mathrm{O}_{3}$ content, as shown in Figure 2. From Table 4, it can be inferred that all mechanical properties of 
various composites decreased with the overall increase in the $\mathrm{Bi}_{2} \mathrm{O}_{3}$ filler content excluding $\mathrm{LDPE}+\mathrm{Bi}_{2} \mathrm{O}_{3}(10 \%)$. This could be attributed to the fact that the low tensile strength of the LPDE compound being used in the experiment. The highest tensile strength of $15.51 \mathrm{MPa}$ was achieved with the LDPE composite that had $10 \mathrm{wt} \% \mathrm{Bi}_{2} \mathrm{O}_{3}$ nanofiller. However, an increase in $\mathrm{Bi}_{2} \mathrm{O}_{3}$ filler loading over $10 \mathrm{wt} \%$ reduced the tensile strength. This could be due to the poor adhesion that exists between filler particles and the requisite LDPE matrix which weakened the resultant interfacial zone between the polymer and the particles of $\mathrm{Bi}_{2} \mathrm{O}_{3}$. The outlined weak zone increased with an increase in filler content, thus decreasing the tensile strength and elongation at the break of the composite [37]. Young's modulus was computed from the slope at zero percent within the tensile curve. The outlined trend was similarly observed within the LDPE $+\mathrm{Bi}_{2} \mathrm{O}_{3}(10 \%)$ : there was a slight increase in Young's modulus with the adding $10 \mathrm{wt} \%$ filler content. In essence, the incorporation of $\mathrm{Bi}_{2} \mathrm{O}_{3}$ nanoparticles can enhance the stiffness of LDPE but an additional increase in particle loadings did not lead to a substantial enhancement to the resultant Young's modulus. Ideally, agglomerations take place at higher particle loading thus reducing the total surface area of the respective nanoparticles [38].

Table 4. Results of mechanical properties of LDPE and its composites.

\begin{tabular}{ccccc}
\hline Sample & $\begin{array}{c}\mathbf{B i}_{2} \mathbf{O}_{\mathbf{3}} \text { Loading } \\
\mathbf{( w t} \%)\end{array}$ & $\begin{array}{c}\text { Tensile } \\
\text { Strength } \\
\mathbf{( M P a )}\end{array}$ & $\begin{array}{c}\text { Elongation @ } \\
\text { Break } \\
\mathbf{( \% )}\end{array}$ & $\begin{array}{c}\text { Young's } \\
\text { Modulus } \\
\text { (MPa) }\end{array}$ \\
\hline Pure LDPE & 0 & $14.77 \pm 0.60$ & $378 \pm 19$ & $355 \pm 36$ \\
LB-5 & 5 & $14.19 \pm 1.29$ & $356 \pm 18$ & $355 \pm 13$ \\
LB-10 & 10 & $15.51 \pm 0.43$ & $374 \pm 22$ & $378 \pm 16$ \\
LB-15 & 15 & $13.09 \pm 0.98$ & $335 \pm 48$ & $350 \pm 14$ \\
\hline
\end{tabular}

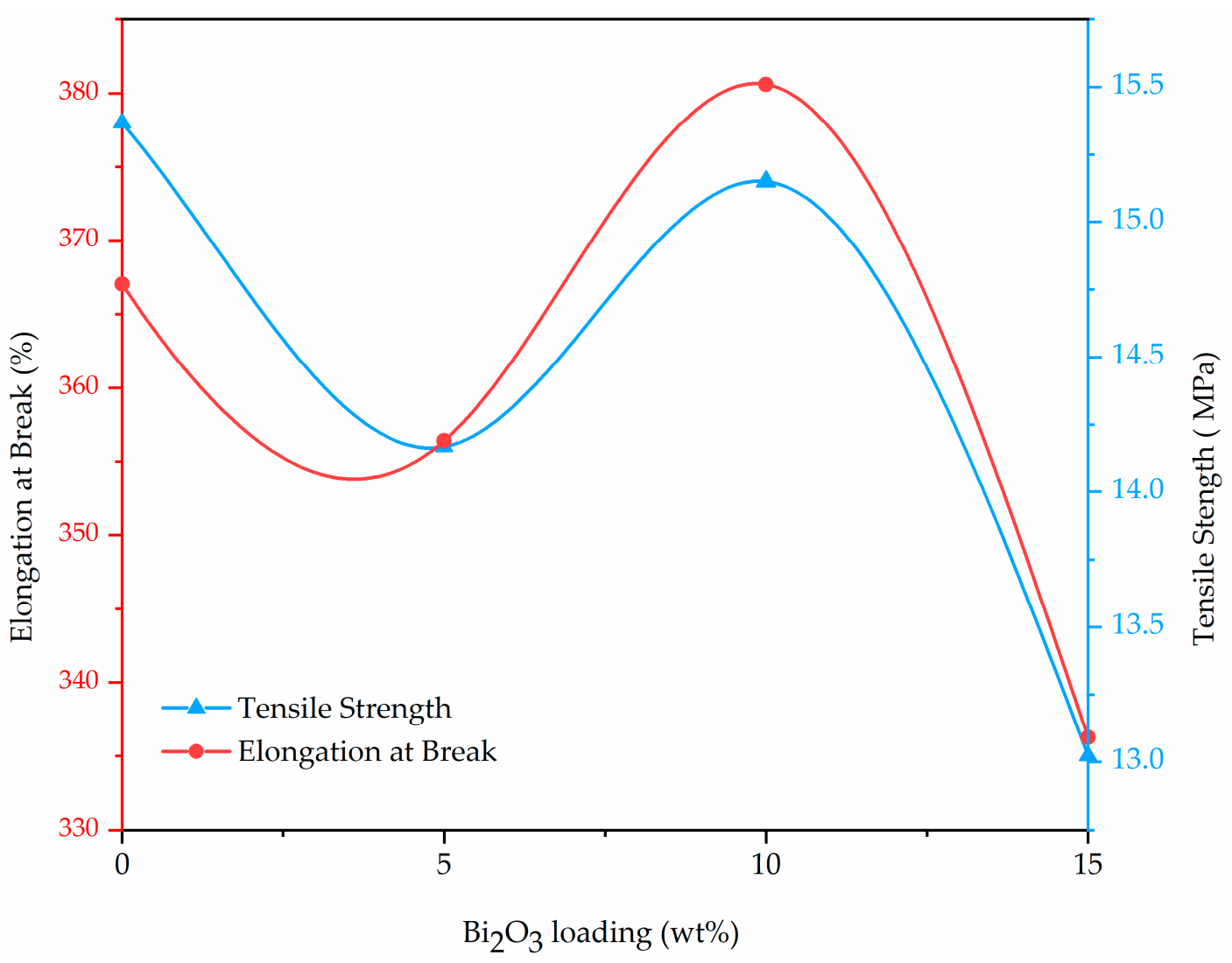

Figure 2. Effect of $\mathrm{wt} \%$ of $\mathrm{Bi}_{2} \mathrm{O}_{3}$ on the mechanical properties of LDPE. 


\subsection{X-ray Diffraction}

The XRD patterns for pure $\mathrm{Bi}_{2} \mathrm{O}_{3}$, pure LDPE, and several quantities of $\mathrm{Bi}_{2} \mathrm{O}_{3}$ with LDPE are displayed in Figure 3. The appearance of diffraction peaks/shoulders at $2 \theta=27.80^{\circ}, 31.73^{\circ}, 32.70^{\circ}, 47.20 \circ, 55.22^{\circ}, 56.48^{\circ}, 57.74^{\circ}$, and $76.47^{\circ}$ is consistent with the dominant diffraction $2 \theta$ angles of the $\beta$-phase of tetragonal $\mathrm{Bi}_{2} \mathrm{O}_{3}$ crystal structure [4]. Figure 3 outlines numerous peaks that correspond to the orthorhombic unit cell of polyethylene. For these peaks, the lattice parameters include $a=7.39 \AA, b=4.93 \AA$, and $c=2.52 \AA$. The unit cell structures of 110 , and the reflection of 200 planes, have two main peaks at $21^{\circ}$ and $24^{\circ}$ respectively. The results that were obtained in this experiment confirm the results of the previous study [4]. On the other hand, two other peaks are known to be located at $30^{\circ}$ and $36^{\circ}$, which correspond to reflection planes of 210 and 020, respectively $[39,40]$. What is more, other weak peaks are located ranging from $40^{\circ}$ to $60^{\circ}$ [40]. As such, the role of $\mathrm{Bi}_{2} \mathrm{O}_{3}$ with LDPE can be assumed affirmatively. In essence, the addition of $\mathrm{Bi}_{2} \mathrm{O}_{3}$ seems under slight variation in its position relative to the main peaks at $21^{\circ}$ and $24^{\circ}$. Even so, the accumulation of $\mathrm{Bi}_{2} \mathrm{O}_{3}$ affected the overall original LDPE structure significantly. There is a new peak at approximately $28^{\circ}$ that is characteristic of a high quantity of bismuth concentration and is linked to the reflection plane 120. Table 5 outlines the values of crystallite size computed using Scherrer's equation. From the calculations, the crystalize size of $\mathrm{Bi}_{2} \mathrm{O}_{3}$ within the LDPE matrix as computed by Scherrer's equation ranges from $18.39 \mathrm{~nm}$ to $18.49 \mathrm{~nm}$. A closer look at the results reveals no considerable difference in the respective crystallite size of the filler particles. The noted slight difference in the overall crystallite size can be attributed to the crystallite size effect.

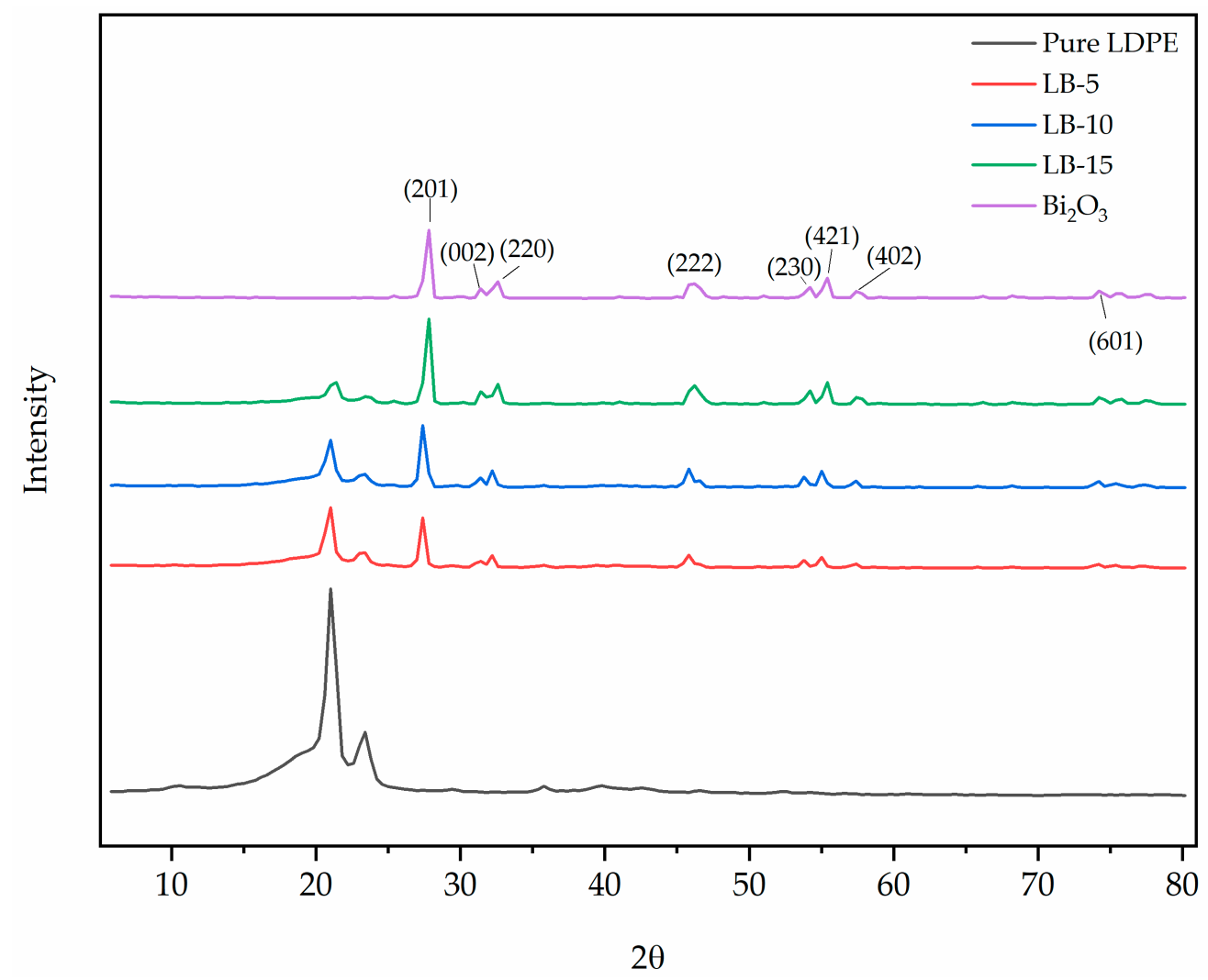

Figure 3. XRD patterns of pure $\mathrm{LDPE}, \mathrm{Bi}_{2} \mathrm{O}_{3}$ and its composites. 
Table 5. Crystallite size of the LDPE composites.

\begin{tabular}{cccc}
\hline Sample & $\mathbf{2 \theta}$ & $\begin{array}{c}\text { Scherrer Crystallite } \\
\text { Size (nm) }\end{array}$ & FWHM \\
\hline Pure LDPE & 21 & 9.52 & 0.8400 \\
Pure $\mathrm{Bi}_{2} \mathrm{O}_{3}$ & 27.8 & 18.41 & 0.4400 \\
$\mathrm{LB}-5$ & 27.4 & 18.39 & 0.4400 \\
$\mathrm{LB}-10$ & 27.4 & 18.39 & 0.4400 \\
$\mathrm{LB}-15$ & 27.8 & 18.41 & 0.4400 \\
\hline
\end{tabular}

\subsection{Morphology}

The surface morphology was determined by SEM. The morphology of various LDPE composites that have $0 \mathrm{wt} \%, 5 \mathrm{wt} \%, 10 \mathrm{wt} \%$ and $15 \mathrm{wt} \% \mathrm{Bi}_{2} \mathrm{O}_{3}$ addition is shown in Figure 4 (Details regarding the density of $\mathrm{Bi}$ atoms in the nanocomposites according to the analysis of SEM-EDS images are shown in the Supplementary Materials, Figures S1-S4). There are no observable particles on the surface of the pure LDPE composite; nonetheless, in the experiment, there was an observed even distribution of particles that dispersed more densely with increased loading, especially in the case of LDPE composites that had $5 \mathrm{wt} \%, 10 \mathrm{wt} \%$ and $15 \mathrm{wt} \%$ added $\mathrm{Bi}_{2} \mathrm{O}_{3}$. The dispersion quality of the nanoparticles into the LDPE was observed to differ based on the overall concentration of the nanoparticle. It is possible that some particles could have settled down as the mixture settled because of the difference in chemical structure and physical properties of both the polymer and nanoparticles despite the mixing process being uniform. This could further be attributed to higher density and/or lack of interaction or bonding with various polymer pellets during the heating process [41]. Nevertheless, the composite that had a $15 \mathrm{wt} \%$ filler load showed the agglomeration of filler particles thus forming larger particles. This must be minimized for the composites to perform better.

a)

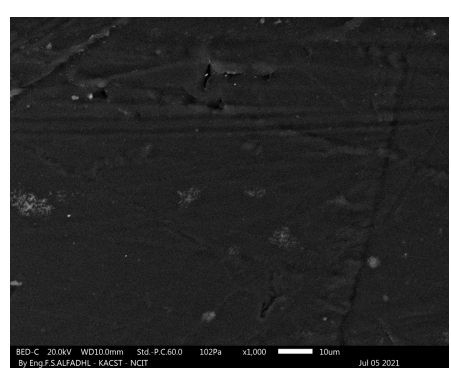

c)

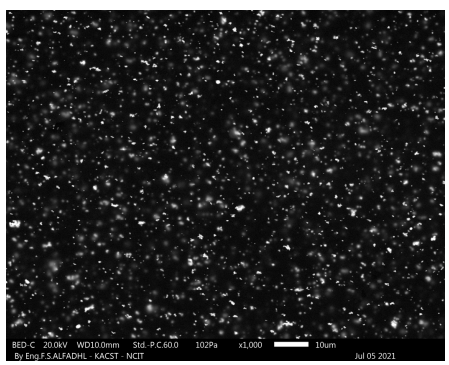

b)

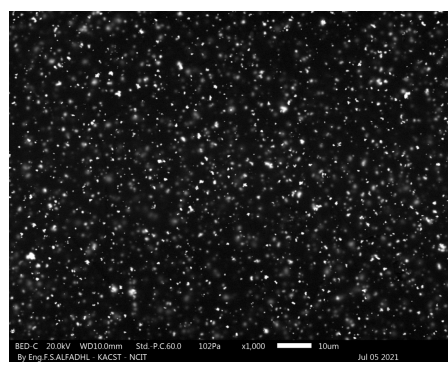

d)

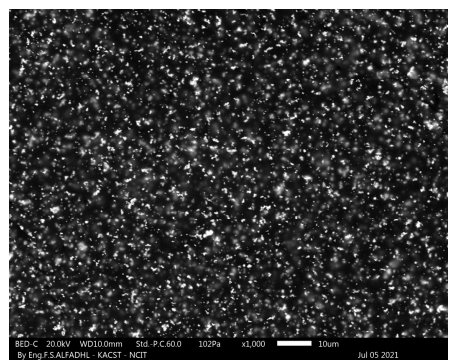

Figure 4. The surface morphology of LDPE nanocomposites (a) pure LDPE (b) $5 \mathrm{wt} \% \mathrm{Bi}_{2} \mathrm{O}_{3}$ (c) $10 \mathrm{wt} \% \mathrm{Bi}_{2} \mathrm{O}_{3}$ and (d) $15 \mathrm{wt} \% \mathrm{Bi}_{2} \mathrm{O}_{3}$. 


\section{Shielding Properties and Application}

\subsection{Shielding Efficiency of the Polymer Composites in Low Energies Applications}

In Equation (2), the Lambert-Beer law is used to determine the attenuation characteristics of a shielding material by calculating the linear attenuation coefficient $(\mu)\left(\mathrm{cm}^{-1}\right)$ or mass attenuation coefficient $\left(\mu_{\mathrm{m}}\right.$ or $\left.\mu / \rho\right)\left(\mathrm{cm}^{2} \mathrm{~g}^{-1}\right)$

$$
\frac{I}{I_{0}}=e^{-\left(\frac{\mu}{\rho}\right) \rho x}
$$

where $I_{0}$ is the initial intensity and $I$ is the remaining radiation intensity $(I)$ after traversing a layer $(x)$ of the composite material considering the density of the absorber $(\rho)$. The experiment evaluated $\mu$ and $\mu_{\mathrm{m}}$ of the $\mathrm{Bi}_{2} \mathrm{O}_{3}$ composite samples based on the LDPE polymer and the impact of the concentration of the $\mathrm{Bi}_{2} \mathrm{O}_{3}$ materials on the polymers. We used an X-ray source and an ionization chamber detector configuration (Figure 5) in a sequence of irradiation. The discs sample holder was placed in between to estimate the intensity of the attenuated beams. Three filler concentrations of LDPE $(5 \%, 10 \%$, and $15 \%)$ were prepared in discs with a diameter of $2 \mathrm{~cm}$ each. The irradiation procedures were conducted using $1.80 \mathrm{~cm}^{2}$ collimator size and $30 \mathrm{~s}$ acquisition time. The $\mu$ values for the composite samples were determined using the intensity values with no disks and with discs for $I_{0}$ and $I$ determination, respectively.

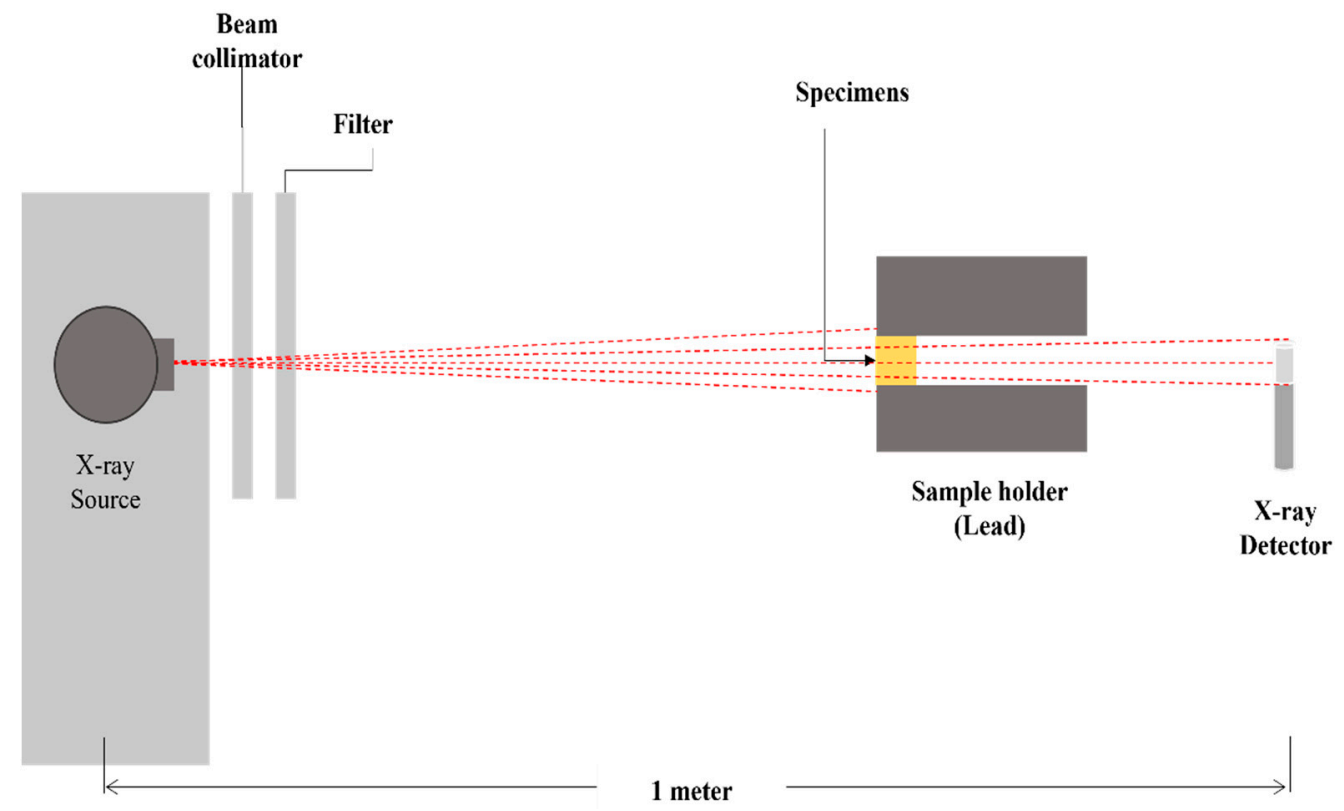

Figure 5. The experimental setup used for shielding efficiency proposed composite materials.

Table 6 shows the $X$-ray irradiation qualities used using a narrow beam spectrum condition allowing only primary photons to pass through the attenuating material to contribute to the detected signal [42]. Using SpekCalc software and for illustration, Figure 6 confirms the effective energy stated in ISO-4037 for the applied voltage of $120 \mathrm{kVp}$ with filters provided in Table 6. 
Table 6. Narrow X-ray spectrum qualities used (Adopted from ISO-4037 [42]).

\begin{tabular}{ccccccc}
\hline \multirow{2}{*}{$\begin{array}{c}\text { Shortened } \\
\text { Name }\end{array}$} & $\begin{array}{c}\text { Tube } \\
\text { Potential } \\
(\mathbf{k V )}\end{array}$ & $\begin{array}{c}\text { Effective } \\
\text { Energy }\end{array}$ & \multicolumn{4}{c}{ Additional Filtration Thickness } \\
\cline { 5 - 7 } & & $\mathbf{k e V )}$ & $\mathbf{m m ~ P b}$ & $\mathbf{m m ~ S n}$ & $\mathbf{m m ~ C u}$ & $\mathbf{m m ~ A l}$ \\
\hline N-60 & 60 & 47.9 & - & - & 0.631 & 3.912 \\
N-100 & 100 & 83.3 & - & - & 5.027 & 3.920 \\
N-120 & 120 & 100 & - & 1.013 & 5.027 & 3.950 \\
N-150 & 150 & 118 & - & 2.605 & - & 3.903 \\
N-200 & 200 & 165 & 1.028 & 3.004 & 2.032 & 3.901 \\
N-250 & 250 & 207 & 3.099 & 2.062 & - & 3.925 \\
N-300 & 300 & 248 & 5.152 & 3.016 & - & 3.929 \\
\hline
\end{tabular}

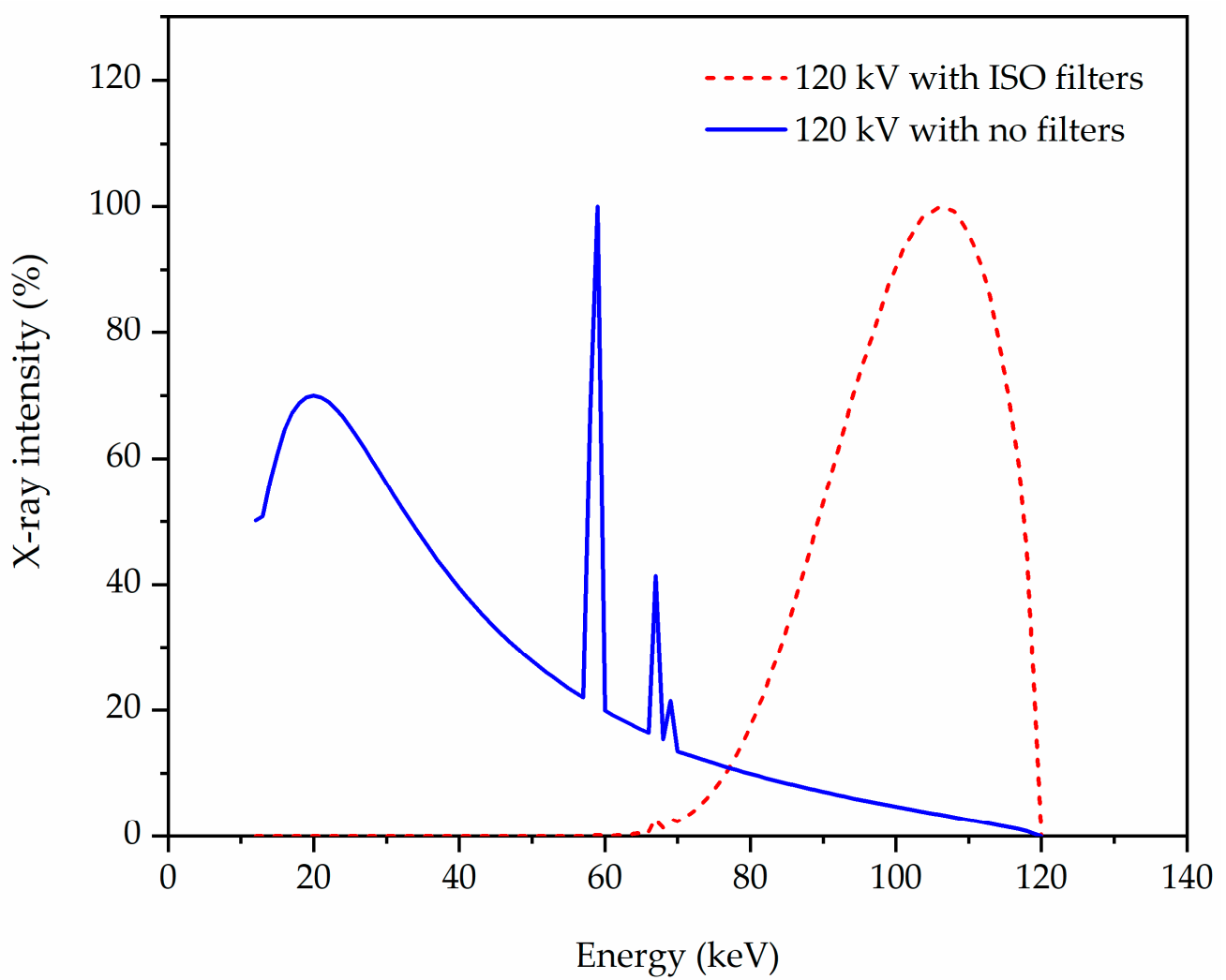

Figure 6. The distribution of the number of X-rays for $120 \mathrm{kVp}$ extracted from SpekCalc with no filters and with ISO filter.

To validate our outcomes, the experimental values of the $\mu_{\mathrm{m}}$ were obtained for the studied samples against energy (E) and were then compared to the calculated values (XCOM database) [43,44].

The attention efficiency of studied samples could be further examined by the halfvalue layer (HVL) and mean free path (MPF). The definition of these radiation protection quantities could be the thickness of the examined material needed to reduce the primary radiation to $50 \%$ and $36.8 \%$ respectively. They depend highly on energy and it can be said that efficient shielding has low HVL and MFP values.

$$
\begin{gathered}
H V L=\frac{0.693}{\mu} \\
M F P=\frac{1}{\mu}
\end{gathered}
$$


The radiation protection efficiency (RPE) could be also used as an indication of the shielding ability of the composite samples by knowing the intensity values measured with and without samples [14]:

$$
\mathrm{RPE}=\left(1-\frac{I}{I_{0}}\right) \times 100(\%)
$$

\subsection{Shielding Ability Investigation of the Polymer Composites}

The shielding ability of composites based on the LDPE polymer was examined in attenuating 40.9-248 keV X-ray beams. The composite materials were developed, mixed with different percentages of $\mathrm{Bi}_{2} \mathrm{O}_{3}$ as filler, and eventually shaped into discs. The setup in Figure 5 used experimentally using narrow-spectrum X-ray beams to determine $I_{o}$ and $I$ when the samples were placed, allowing to calculate the corresponding $\mu$ at different incident beam energies using Equation (2). Figure 7 shows the behavior of the measured $\mu$ against energy for the studied composites based on LDPE polymer prepared in different filler percentages of $5 \%, 10 \%$ and $15 \%$. The $\mu$ values were observed to decrease with energy and the composite coded LB-15 containing $15 \%$ of the $\mathrm{Bi}_{2} \mathrm{O}_{3}$ possesses the highest attenuation across all energies of the incident beams compared to other composites. It is clear that the fillers have enhanced the efficiency compared to pure LDPE especially in low energy below $200 \mathrm{keV}$ region where the predominant mechanism is photoelectric absorption which has a strong dependency on the incoming photon energy $\left(1 / E^{3}\right)$ and the atomic number of the material $\left(Z^{4.5}\right)[45]$.

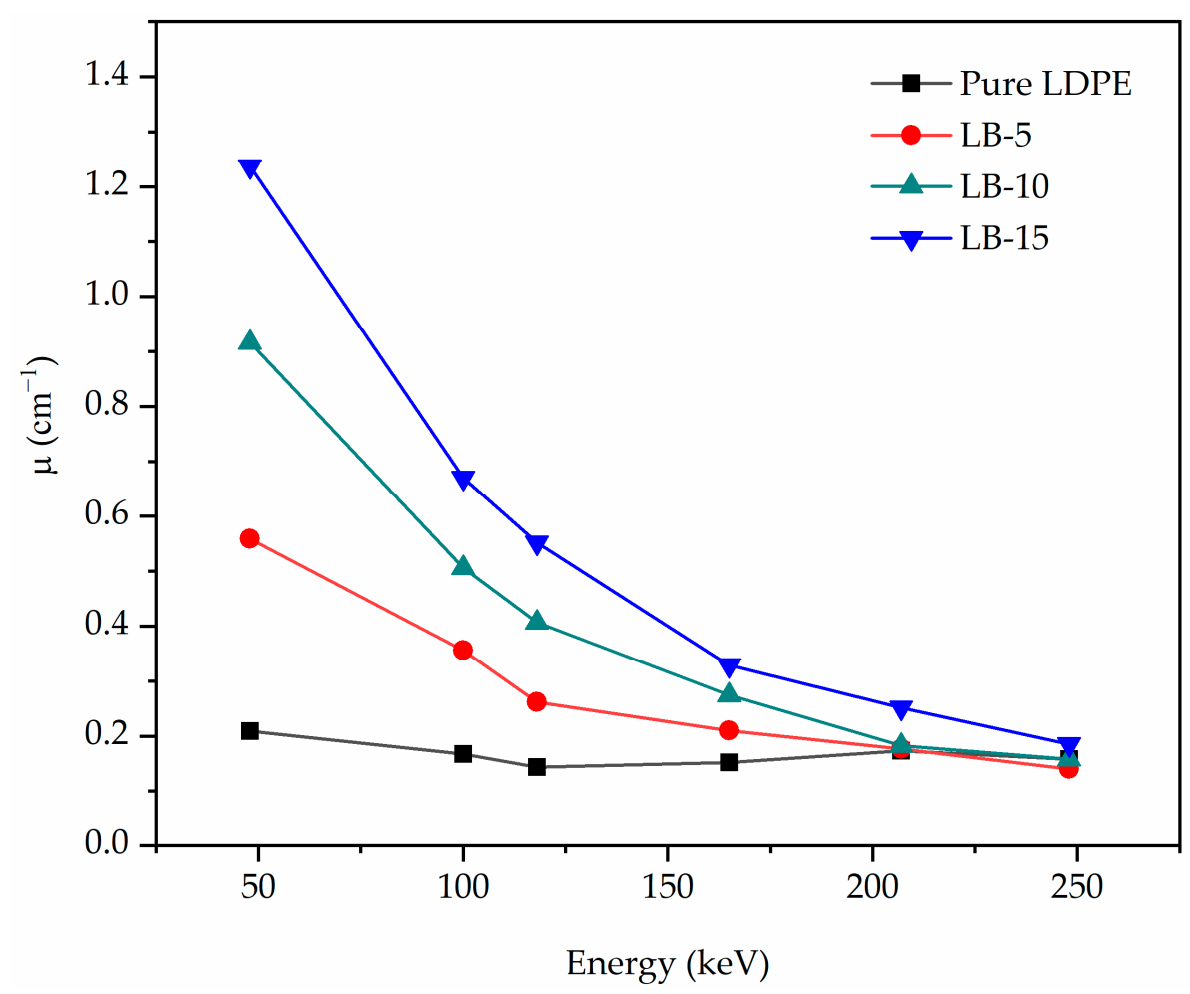

Figure 7. The measured linear attenuation coefficient against incident beam energy.

For verification purposes of the experimentally measured results, Table 7 illustrates the measured values of $\mu_{\mathrm{m}}$ and the calculated results of $\mu_{\mathrm{m}}$ extracted from the XCOM calculator based on the NIST database for the present composite samples. It was revealed that the measured results of $\mu_{\mathrm{m}}$ and the calculated $\mu_{\mathrm{m}}$ were close with an average error of $7.4 \%$. The disagreements could result from experimental errors such as disc placement, the composites densities and the dispersion quality of the fillers in the matrix affecting the evaluation of $\mu$ values and eventually $\mu_{\mathrm{m}}$. 
Table 7. The experimental and calculated values of the mass attenuation coefficient.

\begin{tabular}{|c|c|c|c|c|c|c|c|c|}
\hline \multirow{2}{*}{$\begin{array}{c}\text { Energy } \\
(\mathrm{keV})\end{array}$} & \multicolumn{2}{|c|}{ Pure LDPE } & \multicolumn{2}{|l|}{ LB-5 } & \multicolumn{2}{|l|}{ LB-10 } & \multicolumn{2}{|l|}{ LB-15 } \\
\hline & Exp. & Cal. & Exp. & Cal. & Exp. & Cal. & Exp. & Cal. \\
\hline 47.90 & $0.2094 \pm 0.0035$ & 0.1987 & $0.5589 \pm 0.0041$ & 0.5775 & $0.9164 \pm 0.0062$ & 0.9562 & $1.2369 \pm 0.0077$ & 1.3350 \\
\hline 100 & 0024 & & $360 \pm 0.0030$ & 0.40 & $61 \pm 0.0030$ & 0.6485 & $0.6696 \pm 0.0032$ & 0.8883 \\
\hline 118.00 & $0.1535 \pm 0.0022$ & 0.1620 & $0.2619 \pm 0.0027$ & 0.3171 & $0.4067 \pm 0.0028$ & 0.4721 & $0.5520 \pm 0.0029$ & 0.6271 \\
\hline 165.00 & $0.1520 \pm 0.0017$ & 0.1478 & $0.2010 \pm 0.0019$ & 0.2109 & $0.2745 \pm 0.0025$ & 0.2739 & $0.3287 \pm 0.0024$ & 0.3369 \\
\hline 207.00 & $0.1432 \pm 0.0011$ & 0.1378 & $0.1768 \pm 0.0017$ & 0.1716 & $0.1824 \pm 0.0025$ & 0.2053 & $0.2515 \pm 0.0023$ & 0.2391 \\
\hline 248.00 & $0.1382 \pm 0.0020$ & 0.1298 & $0.1403 \pm 0.0014$ & 0.1501 & $0.1579 \pm 0.0022$ & 0.1704 & $0.1849 \pm 0.0020$ & 0.1908 \\
\hline
\end{tabular}

The attenuation ability of a shield could be illustrated using the HVL and MFP values in Figures $8 \mathrm{a}$ and $8 \mathrm{~b}$. In this examination, the outcomes show that a thinner thickness of fillers is needed to attenuate the X-ray beams compared to the pure LDPE polymer. Particularly, the thickness of pure LDPE required to absorb 50\% of the X-rays is almost four times the thickness of the $\mathrm{LDPE}+\mathrm{Bi}_{2} \mathrm{O}_{3}(15 \%)$ composite.
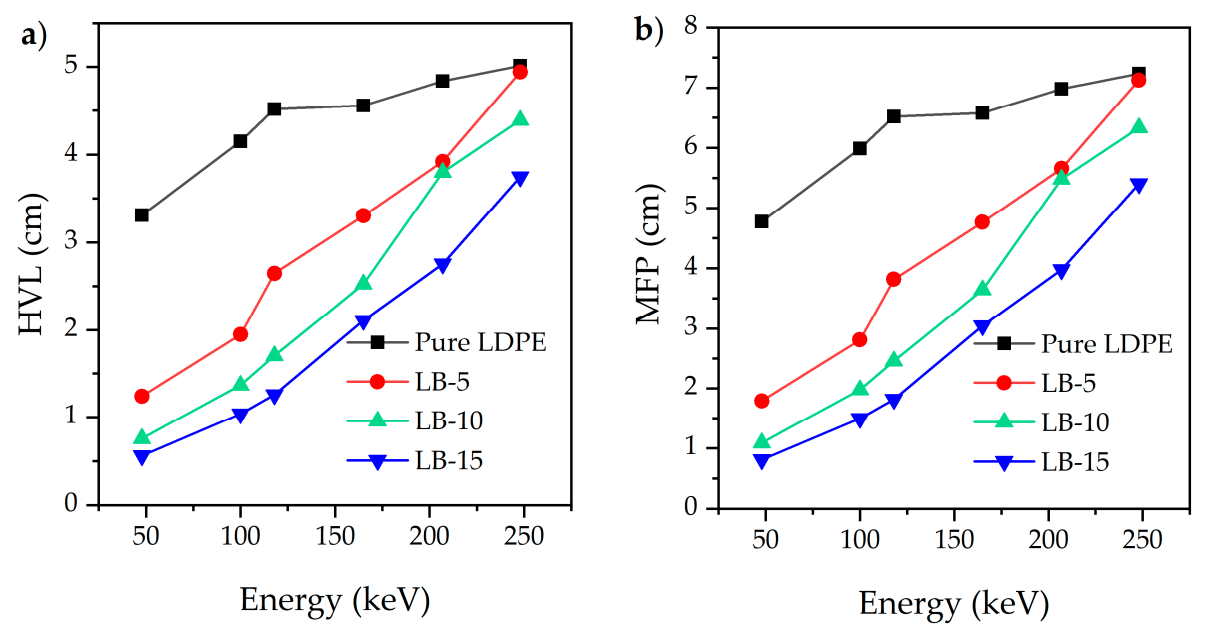

Figure 8. (a) HVL and (b) MFP values against energy for the composite samples prepared in this study.

The results of RPE in Table 8 show that around a $1.60 \mathrm{~cm}$ thick shield of the composite with $15 \%$ filler could reduce approximately $40 \%$ of the incident beam at $100 \mathrm{keV}$. Increasing the thickness of the samples would allow them to be a potential choice for X-ray shielding in diagnostic radiology departments where the energy is used commonly below $100 \mathrm{keV}$ at hospitals using kilovoltage X-rays.

Table 8. The RPE values in \% for the samples prepared in this study.

\begin{tabular}{ccccc}
\hline Energy (keV) & Pure LDPE & LB-5 & LB-10 & LB-15 \\
\hline 47.90 & 17.11 & 44.17 & 76.52 & 79.16 \\
100.00 & 14.02 & 23.17 & 46.95 & 40.24 \\
118.00 & 13.90 & 31.02 & 55.08 & 57.22 \\
165.00 & 12.06 & 23.90 & 47.43 & 50.34 \\
207.00 & 12.73 & 19.66 & 35.21 & 34.08 \\
248.00 & 14.37 & 16.84 & 25.05 & 27.31 \\
\hline
\end{tabular}

The material will have better attenuation ability if it has lower HVL and MFP values. Figure 8 clearly shows that the HVL and MFP are energy-dependent. Therefore, the HVL and MFP values of the composite sample with $15 \mathrm{wt} \%$ of $\mathrm{Bi}_{2} \mathrm{O}_{3}$ with the best performance against radiation were chosen for comparison purposes with other materials or composites in the literature at $100 \mathrm{keV}$. The comparison results in Table 9 showed the $\mathrm{Bi}_{2} \mathrm{O}_{3}-\mathrm{LDPE}$ composites possess low values of HVL and MFP meaning better attenuation ability among other materials. 
Table 9. Comparison of the measured HVL and MFP outcomes with other materials in the literature at $100 \mathrm{keV}$.

\begin{tabular}{cccc}
\hline Study & Composites & HVL (cm) & MFP (cm) \\
\hline This study & LDPE 85\% + $\mathrm{Bi}_{2} \mathrm{O}_{3} 15 \%$ & 1.03 & 1.50 \\
Almurayshid, et al. 2021 [45] & HDPE 85\% + W 15\% & 1.18 & 1.63 \\
Almurayshid, et al. 2021 [45] & HDPE 85\% + Mo 15\% & 2.29 & 3.30 \\
(Alavian and Tavakoli-Anbaran, 2019) [46] & LDPE 99\% + W 1\% & - & 4.27 \\
(Gurler and Akar-Tarim, 2016) [47] & Concrete (NBS) & 1.81 & 2.62 \\
\hline
\end{tabular}

\section{Conclusions}

This study aimed to characterize a potential $\mathrm{Pb}$-free and light-weighted shielding material based on LDPE polymer. The different weight percentages of the components of $\mathrm{Bi}_{2} \mathrm{O}_{3}$ within the final products could be linked to the variation in densities of the composites. The LDPE $+\mathrm{Bi}_{2} \mathrm{O}_{3}(15 \%)$ that had $15 \mathrm{wt} \%$ had higher bismuth composition compared to its LDPE counterparts. This can be affirmed by the SEM images which showed that the interaction between the polymer and the respective bismuth oxide can result in homogenous distribution and dispersion. Analysis using XRD revealed that the crystallite size ranged from $18.39 \mathrm{~nm}$ to $18.49 \mathrm{~nm}$ as determined based on Scherrer's equation. The resultant minor difference could be attributed to the crystallite size effect. In the TG curves of the entire composites, one-stage degradation is present. The first degradation temperature is $459^{\circ} \mathrm{C}$ that shows thermal stability until $600^{\circ} \mathrm{C}$.

The attenuation efficiency of the proposed materials was tested in terms of $\mu, \mu_{\mathrm{m}}$, HVL, and MFP by measuring the transmitted radiation through the proposed shields using a photon energy range up to $248 \mathrm{keV}$. Clear enhancement of the attenuation ability was observed when the percentage of filler to the polymer was increased specifically below $150 \mathrm{keV}$. A future direction of this study could be utilizing the proposed materials to determine their performance in higher energy ranges and neutrons. In addition, increasing the thickness of the proposed composite samples or increasing the percentage of the filler in the polymer could offer a potential shield for low-energy radiation application.

Supplementary Materials: The following are available online at https://www.mdpi.com/article/10 .3390 / polym13183081/s1, Figure S1: SEM-EDS images of pure LDPE, Figure S2: SEM-EDS images of LDPE composite containing a $5 \mathrm{wt} \%$ loading of $\mathrm{Bi}_{2} \mathrm{O}_{3}$, Figure S3: SEM-EDS images of LDPE composite containing a $10 \mathrm{wt} \%$ loading of $\mathrm{Bi}_{2} \mathrm{O}_{3}$, Figure S4: SEM-EDS images of LDPE composite containing a $10 \mathrm{wt} \%$ loading of $\mathrm{Bi}_{2} \mathrm{O}_{3}$.

Author Contributions: Conceptualization, M.A. (Mohammed Alsuhybani) and S.A. (Saad Alshahri); methodology, M.A. (Mohammed Alsuhybani), A.A., S.A. (Salha Alotaibi) and M.A. (Mohammed Alsuhybani); Data analysis; M.A. (Mohammed Alsuhybani), E.A., A.A. and S.A. (Salha Alotaibi); characterization; M.A. (Mohammed Alsuhybani), A.A. and S.A. (Salha Alotaibi); writing-original draft preparation, all authors; writing-review and editing, S.A. (Saad Alshahri), M.A. (Mohammed Alsuhybani), E.A. and M.A. (Mansour Almurayshid); visualization, E.A, A.A. and S.A. (Salha Alotaibi); supervision, M.A. (Mohammed Alsuhybani) and S.A. (Saad Alshahri). All authors have read and agreed to the published version of the manuscript.

Funding: This research received no external funding.

Acknowledgments: The authors would like to thank King Abdulaziz City for Science and Technology for providing all the necessary lab facilities and equipment for this work. We are very much grateful to Alshammari for providing us access to the facilities in the polymer-processing lab. The authors are also grateful to the radiation calibration lab team for their help in measuring the shield performance, Fadhl Alfadhl for SEM imaging, Raed BinKhnin for TGA analysis and Abdulrahman Alshahrani <ashahrani@kacst.edu.sa> Alshahrani for mechanical testing.

Conflicts of Interest: The authors declare no conflict of interest. 


\section{References}

1. Alavian, H.; Tavakoli-Anbaran, H. Comparative study of mass attenuation coefficients for LDPE/metal oxide composites by Monte Carlo simulations. Eur. Phys. J. Plus 2020, 135, 82. [CrossRef]

2. Harish, V.; Nagaiah, N.; Kumar, H. Lead oxides filled isophthalic resin polymer composites for gamma radiation shielding applications. Indian J. Pure Appl. Phys. 2012, 50, 847-850.

3. Martin, J.E. Physics for radiation protection: A handbook. John Wiley \& Sons, Inc.: Ann Arbor, MI, USA, 2006 ; pp. $367-421$.

4. Ambika, M.; Nagaiah, N.; Harish, V.; Lokanath, N.; Sridhar, M.; Renukappa, N.; Suman, S. Preparation and characterisation of Isophthalic- $\mathrm{Bi}_{2} \mathrm{O}_{3}$ polymer composite gamma radiation shields. Radiat. Phys. Chem. 2017, 130, 351-358. [CrossRef]

5. Atashi, P.; Rahmani, S.; Ahadi, B.; Rahmati, A. Efficient, flexible and lead-free composite based on room temperature vulcanizing silicone rubber $/ \mathrm{W} / \mathrm{Bi}_{2} \mathrm{O}_{3}$ for gamma ray shielding application. J. Mater. Sci.: Mater. Electron. 2018, 29, 12306-12322. [CrossRef]

6. Nambiar, S.; Yeow, J.T. Polymer-composite materials for radiation protection. ACS Appl. Mater. Interfaces 2012, 4, 5717-5726. [CrossRef] [PubMed]

7. Shik, N.A.; Gholamzadeh, L. X-ray shielding performance of the EPVC composites with micro-or nanoparticles of WO3, PbO or Bi2O3. Appl. Radiat. Isot. 2018, 139, 61-65. [CrossRef]

8. Fontainha, C.; Baptista-Neto, A.; Faria, L. Polymer-based Nanocomposites of $\mathrm{P}(\mathrm{VDF}-\mathrm{TrFE}) / \mathrm{Bi}_{2} \mathrm{O}_{3}$ Applied to X-ray Shielding. J. Mater. Sci. 2016, 4, 16-24.

9. Jamil, M.; Hazlan, M.H.; Ramli, R.M.; Azman, N.Z.N. Study of electrospun PVA-based concentrations nanofibre filled with Bi2O3 or WO3as potential x-ray shielding material. Radiat. Phys. Chem. 2019, 156, 272-282. [CrossRef]

10. Khan, W.S.; Hamadneh, N.N.; Khan, W.A. Polymer nanocomposites-synthesis techniques, classification and properties. In Science and Applications of Tailored Nanostructures; One Central Press (OCP): Cheshire, UK, 2016; pp. 50-67.

11. Higgins, M.C.M.; Radcliffe, N.A.; Toro-González, M.; Rojas, J.V. Gamma ray attenuation of hafnium dioxide-and tungsten trioxide-epoxy resin composites. J. Radioanal. Nucl. Chem. 2019, 322, 707-716. [CrossRef]

12. Plionis, A.; Garcia, S.; Gonzales, E.; Porterfield, D.; Peterson, D. Replacement of lead bricks with non-hazardous polymer-bismuth for low-energy gamma shielding. J. Radioanal. Nucl. Chem. 2009, 282, 239-242. [CrossRef]

13. El-Fiki, S.; El Kameesy, S.; Nashar, D.; Abou-Leila, M.; El-Mansy, M.; Ahmed, M. Influence of bismuth contents on mechanical and gamma ray attenuation properties of silicone rubber composite. Int. J. Adv. Res. 2015, 3, 1035-1041.

14. Aghaz, A.; Faghihi, R.; Mortazavi, S.; Haghparast, A.; Mehdizadeh, S.; Sina, S. Radiation attenuation properties of shields containing micro and Nano WO3 in diagnostic X-ray energy range. Int. J. Radiat. Res. 2016, 14, 127-131. [CrossRef]

15. Mahmoud, M.E.; El-Khatib, A.M.; Badawi, M.S.; Rashad, A.R.; El-Sharkawy, R.M.; Thabet, A.A. Fabrication, characterization and gamma rays shielding properties of nano and micro lead oxide-dispersed-high density polyethylene composites. Radiat. Phys. Chem. 2018, 145, 160-173. [CrossRef]

16. Mahmoud, M.E.; El-Khatib, A.M.; Badawi, M.S.; Rashad, A.R.; El-Sharkawy, R.M.; Thabet, A.A. Recycled high-density polyethylene plastics added with lead oxide nanoparticles as sustainable radiation shielding materials. J. Clean. Prod. 2018, 176, 276-287. [CrossRef]

17. Afshar, M.; Morshedian, J.; Ahmadi, S. Radiation attenuation capability and flow characteristics of HDPE composite loaded with W, MoS2, and B4C. Polym. Compos. 2019, 40, 149-158. [CrossRef]

18. Lsayed, Z.; Badawi, M.S.; Awad, R.; Thabet, A.A.; El-Khatib, A.M. Study of some $\gamma$-ray attenuation parameters for new shielding materials composed of nano ZnO blended with high density polyethylene. Nucl. Technol. Radiat. Prot. 2019, 34, 342-352. [CrossRef]

19. El-Khatib, A.M.; Abbas, M.I.; Abd Elzaher, M.; Badawi, M.S.; Alabsy, M.T.; Alharshan, G.A.; Aloraini, D.A. Gamma attenuation coefficients of nano cadmium oxide/high density polyethylene composites. Sci. Rep. 2019, 9, 1-11. [CrossRef] [PubMed]

20. Cao, D.; Yang, G.; Bourham, M.; Moneghan, D. Gamma radiation shielding properties of poly (methyl methacrylate)/ $\mathrm{Bi}_{2} \mathrm{O}_{3}$ composites. Nucl. Eng. Technol. 2020, 52, 2613-2619. [CrossRef]

21. Kaçal, M.; Polat, H.; Oltulu, M.; Akman, F.; Agar, O.; Tekin, H. Gamma shielding and compressive strength analyses of polyester composites reinforced with zinc: An experiment, theoretical, and simulation based study. Appl.Phys. A. 2020, 126, 1-15. [CrossRef]

22. Saboori, A.; Dadkhah, M.; Fino, P.; Pavese, M. An overview of metal matrix nanocomposites reinforced with graphene nanoplatelets; mechanical, electrical and thermophysical properties. Metals 2018, 8, 423. [CrossRef]

23. Eid, G.A.; Kany, A.; El-Toony, M.; Bashter, I.; Gaber, F. Application of epoxy/Pb3O4 composite for gamma ray shielding. Arab. J. Nucl. Sci. Appl. 2013, 46, 226-233.

24. Kim, J.; Seo, D.; Lee, B.C.; Seo, Y.S.; Miller, W.H. Nano-W Dispersed Gamma Radiation Shielding Materials. Adv. Eng. Mater. 2014, 16, 1083-1089. [CrossRef]

25. Buzea, C.; Pacheco, I.I.; Robbie, K. Nanomaterials and nanoparticles: Sources and toxicity. Biointerphases 2007, 2, MR17-MR71. [CrossRef] [PubMed]

26. Kazemi, F.; Malekie, S. A Monte Carlo study on the shielding properties of a novel polyvinyl alcohol (PVA)/WO3 composite, against gamma rays, using the MCNPX code. J. Biomed. Phys. Eng. 2019, 9, 465. [CrossRef] [PubMed]

27. Gavrish, V.; Baranov, G.; Chayka, T.; Derbasova, N.; Lvov, A.; Matsuk, Y. Tungsten nanoparticles influence on radiation protection properties of polymers. In IOP Conference Series: Materials Science and Engineering; IOP publishing: Tomsk, Russia, 2015; Volume 110, pp. 1-6. 
28. Liao, Y.-C.; $\mathrm{Xu}$, D.-G.; Zhang, P.-C. Preparation and characterization of $\mathrm{Bi}_{2} \mathrm{O}_{3} / \mathrm{XNBR}$ flexible films for attenuating gamma rays. Nucl. Sci. Tech. 2018, 29, 1-12. [CrossRef]

29. Azman, N.N.; Siddiqui, S.; Hart, R.; Low, I.-M. Effect of particle size, filler loadings and x-ray tube voltage on the transmitted x-ray transmission in tungsten oxide-epoxy composites. Appl. Radiat. Isot. 2013, 71, 62-67. [CrossRef] [PubMed]

30. Belgin, E.E.; Aycik, G. Preparation and radiation attenuation performances of metal oxide filled polyethylene based composites for ionizing electromagnetic radiation shielding applications. J. Radiational Nucl. Chem. 2015, 306, 107-117. [CrossRef]

31. Ambika, M.; Nagaiah, N.; Suman, S. Role of bismuth oxide as a reinforcer on gamma shielding ability of unsaturated polyester based polymer composites. J. Appl. Polym. Sci. 2017, 134, 1-7. [CrossRef]

32. Pavlenko, V.; Cherkashina, N.; Yastrebinsky, R. Synthesis and radiation shielding properties of polyimide/Bi2O3 composites. Heliyon 2019, 5, e01703. [CrossRef]

33. Cherkashina, N.; Pavlenko, A. Synthesis of polymer composite based on polyimide and Bi12SiO20 sillenite. Polym. Plast. Technol. Eng. 2018, 57, 1923-1931. [CrossRef]

34. Roy, P.; Surekha, P.; Raman, R.; Rajagopal, C. Investigating the role of metal oxidation state on the degradation behaviour of LDPE. Polym. Degrad. Stab. 2009, 94, 1033-1039. [CrossRef]

35. Gupta, R.; Badel, B.; Gupta, P.; Bucknall, D.G.; Flynn, D.; Pancholi, K. Flexible Low-Density Polyethylene-BaTiO3 Nanoparticle Composites for Monitoring Leakage Current in High-Tension Equipment. ACS Appl. Nano Mater. 2021, 4, 2413-2422. [CrossRef]

36. Klinkova, L.; Nikolaichik, V.; Barkovskii, N.; Fedotov, V. Thermal stability of $\mathrm{Bi}_{2} \mathrm{O}_{3}$. Russ. J. Inorg. Chem. 2007, 52, 1822-1829. [CrossRef]

37. Sheela, M.; Kamat, V.A.; Kiran, K.; Eshwarappa, K. Preparation and characterization of bismuth-filled high-density polyethylene composites for gamma-ray shielding. Radiat. Prot. Environ. 2019, 42, 180-186.

38. Chee, C.Y.; Song, N.; Abdullah, L.C.; Choong, T.S.; Ibrahim, A.; Chantara, T. Characterization of mechanical properties: Lowdensity polyethylene nanocomposite using nanoalumina particle as filler. J. Nanomater. 2012, 2012, 215978. [CrossRef]

39. Inci, B.; Wagener, K.B. Decreasing the alkyl branch frequency in precision polyethylene: Pushing the limits toward longer run lengths. J. Am. Chem. Soc. 2011, 133, 11872-11875. [CrossRef]

40. Trujillo, M.; Arnal, M.; Müller, A.; Laredo, E.; Bredeau, S.; Bonduel, D.; Dubois, P. Thermal and morphological characterization of nanocomposites prepared by in-situ polymerization of high-density polyethylene on carbon nanotubes. Macromolecules 2007, 40, 6268-6276. [CrossRef]

41. Sabri, J.H.; Mahdi, K.H. A Comparative Study for Micro and Nano shield of (PbO) composite for gamma Radiation. Energy Procedia 2019, 157, 802-814. [CrossRef]

42. ISO 4037-1:2019. Radiological Protection-X and Gamma Reference Radiation for Calibrating Dosemeters and Doserate Meters and for Determining Their Response as a Function of Photon Energy —Part 1: Radiation Characteristics and Production Methods; ISO: Geneva, Switzerland, 2019; ISC, 17, 17.240.

43. Berger, M.J.; Hubbell, J.H.; Seltzer, S.M.; Chang, J.; Coursey, J.S.; Sukumar, R.D.; Zucker, S.; Olsen, K. XCOM: Photon Cross Sections on a Personal Computer; NIST, PML, Radiation Physics Division: Washington, DC, USA, 1987; pp. 87-3597. [CrossRef]

44. El-Sayed, A.; Ali, M.A.M.; Ismail, M.R. Natural fibre high-density polyethylene and lead oxide composites for radiation shielding. Radiat. Phys. Chem. 2003, 66, 185-195. [CrossRef]

45. Almurayshid, M.; Alsagabi, S.; Alssalim, Y.; Alotaibi, Z.; Almsalam, R. Feasibility of polymer-based composite materials as radiation shield. Radiat. Phys. Chem. 2021, 183, 109425. [CrossRef]

46. Alavian, H.; Tavakoli-Anbaran, H. Study on gamma shielding polymer composites reinforced with different sizes and proportions of tungsten particles using MCNP code. Prog. Nucl. Energy 2019, 115, 91-98. [CrossRef]

47. Gurler, O.; Akar-Tarim, U. Determination of radiation shielding properties of some polymer and plastic materials against gamma-rays. Acta Phys. Pol. A 2016, 130, 236-238. [CrossRef] 